\title{
Article \\ Serum Amyloid Beta42 Is Not Eliminated by the Cirrhotic Liver: A Pilot Study
}

\author{
Reiner Wiest $^{1}$, Thomas S. Weiss ${ }^{2}\left(\mathbb{D}\right.$, Lusine Danielyan ${ }^{3} \mathbb{D}$ and Christa Buechler ${ }^{4, *(D)}$ \\ 1 Department of Visceral Surgery and Medicine, University Inselspital, 3010 Bern, Switzerland; \\ reiner.wiest@insel.ch \\ 2 Children's University Hospital (KUNO), Regensburg University Hospital, 93053 Regensburg, Germany; \\ thomas.weiss@klinik.uni-regensburg.de \\ 3 Department of Clinical Pharmacology, Institute of Clinical and Experimental Pharmacology and Toxicology, \\ University Hospital of Tuebingen, 72074 Tuebingen, Germany; lusine.danielyan@med.uni-tuebingen.de \\ 4 Department of Internal Medicine I, Regensburg University Hospital, 93053 Regensburg, Germany \\ * Correspondence: christa.buechler@klinik.uni-regensburg.de; Tel.: +49-94-1944-7009
}

Citation: Wiest, R.; Weiss, T.S.; Danielyan, L.; Buechler, C. Serum Amyloid Beta42 Is Not Eliminated by the Cirrhotic Liver: A Pilot Study. J. Clin. Med. 2021, 10, 2669. https:// doi.org/10.3390/jcm10122669

Academic Editors: Davide Giuseppe Ribaldone and Gian Paolo Caviglia

Received: 14 May 2021

Accepted: 16 June 2021

Published: 17 June 2021

Publisher's Note: MDPI stays neutral with regard to jurisdictional claims in published maps and institutional affiliations.

Copyright: (c) 2021 by the authors. Licensee MDPI, Basel, Switzerland. This article is an open access article distributed under the terms and conditions of the Creative Commons Attribution (CC BY) license (https:/ / creativecommons.org/licenses/by/ $4.0 /)$.

\begin{abstract}
Amyloid-beta $(\mathrm{A} \beta)$ deposition in the brain is the main pathological hallmark of Alzheimer disease. Peripheral clearance of $A \beta$ may possibly also lower brain levels. Recent evidence suggested that hepatic clearance of $A \beta 42$ is impaired in liver cirrhosis. To further test this hypothesis, serum A $\beta 42$ was measured by ELISA in portal venous serum (PVS), systemic venous serum (SVS), and hepatic venous serum (HVS) of 20 patients with liver cirrhosis. Mean A $\beta 42$ level was $24.7 \pm 20.4 \mathrm{pg} / \mathrm{mL}$ in PVS, $21.2 \pm 16.7 \mathrm{pg} / \mathrm{mL}$ in HVS, and $19.2 \pm 11.7 \mathrm{pg} / \mathrm{mL}$ in SVS. Similar levels in the three blood compartments suggested that the cirrhotic liver does not clear A $\beta 42$. A $\beta 42$ was neither associated with the model of end-stage liver disease score nor the Child-Pugh score. Patients with abnormal creatinine or bilirubin levels or prolonged prothrombin time did not display higher A $\beta 42$ levels. Patients with massive ascites and patients with large varices had serum $A \beta 42$ levels similar to patients without these complications. Serum $A \beta 42$ was negatively associated with connective tissue growth factor levels $(r=-0.580, p=0.007)$ and a protective role of $A \beta 42$ in fibrogenesis was already described. Diabetic patients with liver cirrhosis had higher A $\beta 42$ levels ( $p=0.069$ for PVS, $p=0.047$ for HVS and $p=0.181$ for SVS), which is in accordance with previous reports. Present analysis showed that the cirrhotic liver does not eliminate $A \beta 42$. Further studies are needed to explore the association of liver cirrhosis, $\mathrm{A} \beta 42$ levels, and cognitive dysfunction.
\end{abstract}

Keywords: portal vein; MELD score; bilirubin; ascites; hepatic clearance; liver cirrhosis

\section{Introduction}

Amyloid-beta $(\mathrm{A} \beta)$ peptides of variable length are produced by proteolysis of amyloid precursor protein (APP). The two most common isoforms of $A \beta$ are 40 and 42 amino acid peptides [1]. Cerebral accumulation of these $A \beta$ peptides is a characteristic feature of Alzheimer disease [2]. Cell surface Low Density Lipoprotein Receptor-related Protein 1 (LRP1) and soluble LRP1 enhance the clearance of brain and circulating A $\beta$. In brain, LRP1 is involved in the transport of $\mathrm{A} \beta$ across the blood-brain barrier. LRP1 also mediates APP internalization and processing, and thereby contributes to A $\beta$ generation [3]. LRP1 downregulation in brain microvessels of Alzheimer patients correlated with $\mathrm{A} \beta$ deposition in the brain [4]. To clarify the in vivo effect of LRP1 on A $\beta$ production/clearance, mice expressing a mutant LRP1 protein, with impaired endocytosis and transcytosis activity, were crossed with a mouse model for Alzheimer disease (which were transgenic mice expressing mutant human APP with both the Swedish (K670N/M671L) and London (V717I) mutations) [3]. Mutant LRP1 finally led to reduced A $\beta$ levels in cerebrospinal fluid and brain interstitial fluid and lower plaque burden [3]. This study provided evidence for a more prominent role of LRP1 in A $\beta$ synthesis than degradation [3]. 
Recent evidence showed that the kidney, the skin, the gastrointestinal tract, and the liver contribute to peripheral $A \beta$ clearance [5]. $A \beta$ was detected in urine of humans, mice, and rabbits [6]. In a mouse model for Alzheimer disease (APP/Presenilin 1 mice expressing human mutant presenilin 1 and a chimeric mouse/human amyloid precursor protein (Mo/HuAPP695swe)) unilateral nephrectomy increased plasma and brain A $\beta$ deposition and reduced $A \beta$ in urine [6]. Whereas the molecules involved in renal clearance of $A \beta$ have not been defined yet, hepatocytes express LRP1, which mediates $A \beta$ uptake. Rat hepatocytes were shown to degradate these peptides or to excrete $A \beta$ into the bile [7]. Detection of $A \beta$ deposits in the human skin and intestine suggested that these tissues also contribute to peripheral clearance [8]. The exact pathways involved are still unknown [7]. Peripheral monocytes and tissue-resident macrophages eliminate $A \beta$ peptides. Thus, tissue-resident macrophages may contribute to $A \beta$ elimination not only in the skin and small intestine but also in tissues such as the liver [7]. Uptake and degradation of $A \beta$ peptides by peripheral blood monocytes was, indeed, impaired in Alzheimer disease patients and this may also apply for tissue-resident phagocytes [9].

A separate study showed that $A \beta$ levels in axillary lymph nodes of Alzheimer transgenic mice were as high as its brain concentrations and assumed that brain-derived $A \beta 40$ and $A \beta 42$ are cleared by lymphoid tissues. The mice used in this study expressed a human isoform of APP with the Swedish mutation, which causes high levels of $A \beta$ and early onset of Alzheimer disease. Interestingly, $A \beta 40$ and $A \beta 42$ levels in the liver and kidney of these mice were hardly detectable [10].

Hepatic catabolism of $A \beta 42$ was demonstrated in mice, and about $60 \%$ of the radiolabeled $A \beta$ peptides accumulated in the liver [11]. $A \beta 42$ protein levels were reduced in human and rodent cirrhotic liver tissues, and plasma $A \beta 42$ levels were high in patients with liver cirrhosis. This may argue for a role of the liver in peptide clearing but may also mean that hepatic release of $A \beta$ peptides is increased in cirrhosis [12,13]. Plasma $A \beta 42$ positively correlated with bilirubin and aspartate aminotransferase (AST) levels and was negatively correlated with albumin, indicating an association between liver function and systemic levels of $A \beta 42$ [12].

Impaired hepatic removal of blood $A \beta 42$ can explain high plasma $A \beta 42$ levels in patients with liver cirrhosis [12]. This may also contribute to low $A \beta$ levels in the cirrhotic liver $[12,13]$. In the healthy human liver V-PLEX ${ }^{\circledR}$ analysis detected $2.5-7.5 \mathrm{pg} / \mathrm{mL} \mathrm{A} \beta 42$ levels, which declined about 10 fold in the cirrhotic liver [13]. Of note, hepatic $A \beta$ protein was also low in Alzheimer disease. A $\beta 42$ protein analyzed by ELISA in postmortem liver lysates of controls was $6.4-20.6 \mathrm{ng} / \mathrm{g}$ and was as low as $0-2.6 \mathrm{ng} / \mathrm{g}$ in the liver of patients with Alzheimer disease [14]. Studies on systemic A $\beta 42$ levels in patients with Alzheimer disease have had mixed results [15]. Whether low hepatic levels are thus, indeed, linked to high systemic concentrations of $A \beta 42$ has not been finally clarified [13,15].

It is important to note that $A \beta 42$ exerts protective functions in the liver. Uptake of $A \beta 42$ peptides by murine hepatic stellate cells suppressed the expression of fibrotic proteins such as transforming growth factor beta (TGFbeta) [13]. TGFbeta strongly contributes to tissue fibrosis and is an excellent inducer of connective tissue growth factor (CTGF) in hepatocytes. Serum CTGF is increased in patients with liver cirrhosis and is related to liver fibrosis [16-18].

$A \beta$ further induced endothelial nitric oxide (NO) synthase in human SV40 immortalized hepatic sinusoidal endothelial cells [13]. NO is a vasodilatory molecule and its bioavailability is reduced in sinusoidal endothelial cells of the cirrhotic liver. This, indeed, contributes to increased intrahepatic vascular resistance and portal hypertension, which is one of the key factors responsible for the development of complications of liver cirrhosis such as varices and ascites [19-21]. Arginine and asymmetric dimethylarginine (ADMA) regulate endothelial function. ADMA is an endogenous inhibitor of NO synthase, whereas arginine can enhance production of NO [21,22]. Plasma levels of ADMA were higher in patients with decompensated than compensated liver cirrhosis, whereas arginine levels did not change $[22,23]$. 
There is some evidence that patients with chronic liver diseases have an increased risk for Alzheimer disease [24]. Non-alcoholic fatty liver disease (NAFLD) is a common disorder and may progress to liver cirrhosis and hepatocellular carcinoma [25]. NAFLD induced Alzheimer disease in wild-type mice and in mice carrying the Swedish APP protein and the $\Delta \mathrm{e} 9$ presenilin 1 mutation but lacking mouse APP protein [26]. Neuronal apoptosis, brain inflammation, and $\beta$-amyloid plaques were increased, whereas brain expression of LRP1 was reduced in both mouse groups when fed a high-fat diet to induce NAFLD [26]. Dyslipidemia and insulin resistance are characteristics of NAFLD, and abnormal lipid metabolism, as well as type 2 diabetes, increased the risk to develop Alzheimer disease [24]. A longitudinal cohort study identified higher brain A $\beta$ levels in cognitively normal subjects who had abnormal triglyceride levels 20 years ago [27]. High low-density lipoprotein and low high-density lipoprotein levels were linked with higher cerebral $A \beta$ in a cohort of patients with no or mild cognitive impairment [28]. Hypercholesterinemia, oxidative stress, and hyperinsulinemia impair $A \beta$ clearance in type 2 diabetes patients, who have a higher risk of developing Alzheimer disease [7].

Analysis of protein levels in portal venous serum (PVS), hepatic venous serum (HVS), and systemic venous serum (SVS) gives some information about hepatic clearance and synthesis of different proteins and metabolites [29]. The liver can produce and eliminate metabolites and, thus, levels in peripheral blood might not represent the concentrations in portal or hepatic venous blood [29]. Different concentrations of metabolites in these blood compartments can also provide some information about their production in certain tissues. High synthesis of, e.g., cytokines in the gut or visceral adipose tissues may increase the concentration in the portal vein relative to the systemic blood $[29,30]$. In case that the production of the cytokine is induced in the liver, levels may be higher in the hepatic than the portal vein [29]. PVS and HVS are not available from healthy persons for ethical issues but can be collected from patients with liver cirrhosis during implantation of a transjugular intrahepatic portosystemic shunt. In these blood samples IL-6 levels were higher in PVS than HVS, demonstrating that IL-6 is cleared by the liver [31]. Impaired liver function was thus associated with higher levels of serum IL-6 [31]. IL-6 is an acute phase protein and regulates liver regeneration and metabolism. Permanently high IL-6 is, nevertheless, detrimental to liver health [32].

An increase of sCD163, which is almost exclusively produced by macrophages, from the portal to the hepatic vein showed that liver macrophages released this protein $[33,34]$. Plasma levels of sCD163 were positively related to the severity of liver disease in patients with liver cirrhosis and indicate activation of Kupffer cells in these patients [33,34].

Resistin in humans is also mainly released by macrophages, and serum levels were induced in liver cirrhosis. Resistin concentrations did, however, not differ between SVS, HVS, and PVS, suggesting that higher serum levels in liver cirrhosis are not a marker of Kupffer cell activation and may be related to the dysfunction of monocytes/macrophages in liver cirrhosis [35].

Chemerin is abundantly expressed in the liver and levels were higher in the hepatic than the portal vein [36-38]. Serum chemerin is a marker for hepatic dysfunction and was low in patients with liver cirrhosis $[39,40]$.

Visfatin is an inflammatory and pro-fibrotic protein, and levels were higher in HVS and PVS when compared to SVS. Whether serum visfatin is changed in patients with liver cirrhosis or is related to liver disease severity has not been finally clarified [35].

Chronic inflammation contributes to the pathogenesis of Alzheimer disease and liver cirrhosis and, thereby, may link liver diseases with cognitive impairment [24,35]. C-reactive protein (CRP) is a routine laboratory marker for inflammation but was not increased in serum of patients with Alzheimer disease [41]. CRP is an acute phase protein synthesized by the liver. Patients with liver cirrhosis have higher systemic CRP. A relationship to the severity of the liver disease did not exist [42].

Here, HVS, PVS, and SVS of patients with liver cirrhosis were used to measure A $\beta 42$. Only a little serum was available, and either $A \beta 40$ or $A \beta 42$ could be analyzed. Regarding 
that systemic $A \beta 42$ is more strongly related to cognitive status [43], and that both peptides were comparably changed in plasma and liver of patients with liver cirrhosis [12,13], A $\beta 42$ was determined.

It was hypothesized that serum A $\beta 42$ is lower in HVS than PVS because of hepatic extraction. Clearance of $\mathrm{A} \beta 42$ by the liver may also contribute to lower serum levels. Moreover, it was postulated that $A \beta 42$ levels increase in patients with more severe liver disease because of impaired removal by the injured liver.

\section{Materials and Methods}

\subsection{Transjugular Intrahepatic Portosystemic Shunt (TIPS)}

Twenty patients with clinically diagnosed liver cirrhosis were included in the study. Etiology of liver disease was alcoholic in 18 and hepatitis $C$ infection in two patients. Patients were treated by TIPS implantation due to complications of liver cirrhosis. This procedure has been described earlier, and TIPS was inserted in the fasted state [44]. During this intervention, samples of the hepatic vein (HVS), of the portal vein (PVS), and of a peripheral vein (SVS) were obtained. Medication and alcohol consumption of the patients were not documented. Patients had not been drinking any alcohol at the time the blood samples were drawn.

Standard laboratory values (such as alanine aminotransferase (ALT), aspartate aminotransferase (AST), or albumin) were measured by the Institute for Clinical Chemistry and Laboratory Medicine at our hospital. The study complied with the Declaration of Helsinki. All patients gave written, informed consent and the study was approved by the ethical committee of the University Hospital of Regensburg.

$G^{*}$ Power3.1.6 analysis using the values of plasma $A \beta 42$ in patients with cirrhosis (excluding patients with hepatitis B virus) and healthy controls published by Wang et al. [12] indicated that seven patients per group are enough to identify higher $A \beta 42$ in patients with liver cirrhosis with an alpha error of 0.05 and a power of 0.80 . More patients may be necessary to differentiate those with compensated and decompensated cirrhosis (because the difference in $A \beta 42$ levels may be smaller in comparison to healthy controls) but there was no study having analyzed $A \beta 42$ levels in serum of these patients so far and the number of patients needed could not be calculated.

\subsection{ELISA}

Human Amyloid $\beta$ (aa1-42) Immunoassay was from R\&D Systems (Wiesbaden, Nordenstadt, Germany). Serum was used undiluted. All of the blood samples were analyzed at one day in parallel. Therefore, inter-assay coefficient of variation (CV) could not be calculated. Intra-assay CV for samples with $A \beta 42<10 \mathrm{pg} / \mathrm{mL}$ was $12.4 \%$, for samples with $\mathrm{A} \beta 42<20 \mathrm{pg} / \mathrm{mL}$ was $12.3 \%$, for samples with $\mathrm{A} \beta 42<30 \mathrm{pg} / \mathrm{mL}$ was $8.1 \%$, and for samples with $A \beta 42<100 \mathrm{pg} / \mathrm{mL}$ was $7.2 \%$. The lowest value of the standard curve was $7.8 \mathrm{pg} / \mathrm{mL}$, and almost all serum levels were greater. Median levels of $\mathrm{A} \beta 42$ were, indeed, about $20 \mathrm{pg} / \mathrm{mL}$ and were nearly three-fold higher than the lowest standard. Therefore, $50 \%$ of the analyzed sera had $A \beta 42$ levels above the concentration of the second standard $(15.6 \mathrm{pg} / \mathrm{mL})$.

Interleukin (IL)-6, connective tissue growth factor (CTGF), chemerin, resistin, visfatin, arginine, and asymmetric dimethylarginine (ADMA) were already measured in patients with liver cirrhosis, and results were published [16,22,31,36,45].

Standards and samples were measured in duplicate, and the means were used for statistical analyses.

\subsection{Statistics}

Data are shown as box plots (median value, range of the values, the first and the third quartile-circles or stars outside the boxes indicate outliers). Shapiro-Wilk test showed that A $\beta 42$ and chemerin were not normally distributed in the different blood compartments. Statistical differences were, therefore, calculated by non-parametric tests, namely the Mann- 
Whitney U Test, the Kruskal-Wallis Test, the Wilcoxon Test, or Friedman test (IBM SPSS Statistics 26.0). IL-6 was normally distributed, and paired $t$-test was used for calculation. Spearman correlations were analyzed by the IBM SPSS Statistics software.

\section{Results}

\subsection{A 442 in Different Blood Compartments of Patients with Liver Cirrhosis}

Serum of 20 patients suffering from clinically diagnosed liver cirrhosis was available for this study. Patients' characteristics are given in Table 1.

Table 1. Patient demographics and laboratory parameters (median values and ranges are shown).

\begin{tabular}{cc}
\hline & Cirrhosis Patients \\
\hline Number & 20 \\
Sex (female/male) & $7 / 13$ \\
MELD score & $9(6-21)$ \\
Age (years) & $52(40-81)$ \\
Child-Pugh score A/B/C/ & $6 / 6 / 8$ \\
C-reactive protein (mg/L) & $9.9(1.0-53.5)$ \\
Albumin (g/L) & $32.9(1.6-42.7)$ \\
Bilirubin (mg/dL) & $1.2(0.5-4.6)$ \\
Quick prothrombin time (\%) & $71(28-100)$ \\
Aspartate aminotransferase (U/L) & $40(11-82)$ \\
Alanine aminotransferase (U/L) & $33(2-68)$ \\
Creatinine (mg/dL) & $1.1(0.5-4.5)$ \\
Ascites: no or little/modest or massive & $8 / 12$ \\
Varices: no or small/large & $7 / 13$ \\
Diabetes no/yes & $12 / 8$ \\
\hline
\end{tabular}

MELD: Model for end-stage liver disease.

A 342 levels were similar in SVS, HVS, and PVS (Friedman test; Figure 1A). A concern is that there were too few patients to identify any differences between the blood compartments. The number of patients was, indeed, too small to confirm higher levels of chemerin in HVS than PVS [36] (Friedman test; Figure 1B). In the current cohort, IL-6 was significantly higher in PVS than HVS, as was reported earlier. The recently described rise of IL-6 in SVS relative to HVS was also identified [31] (paired $t$-test; Figure 1C).
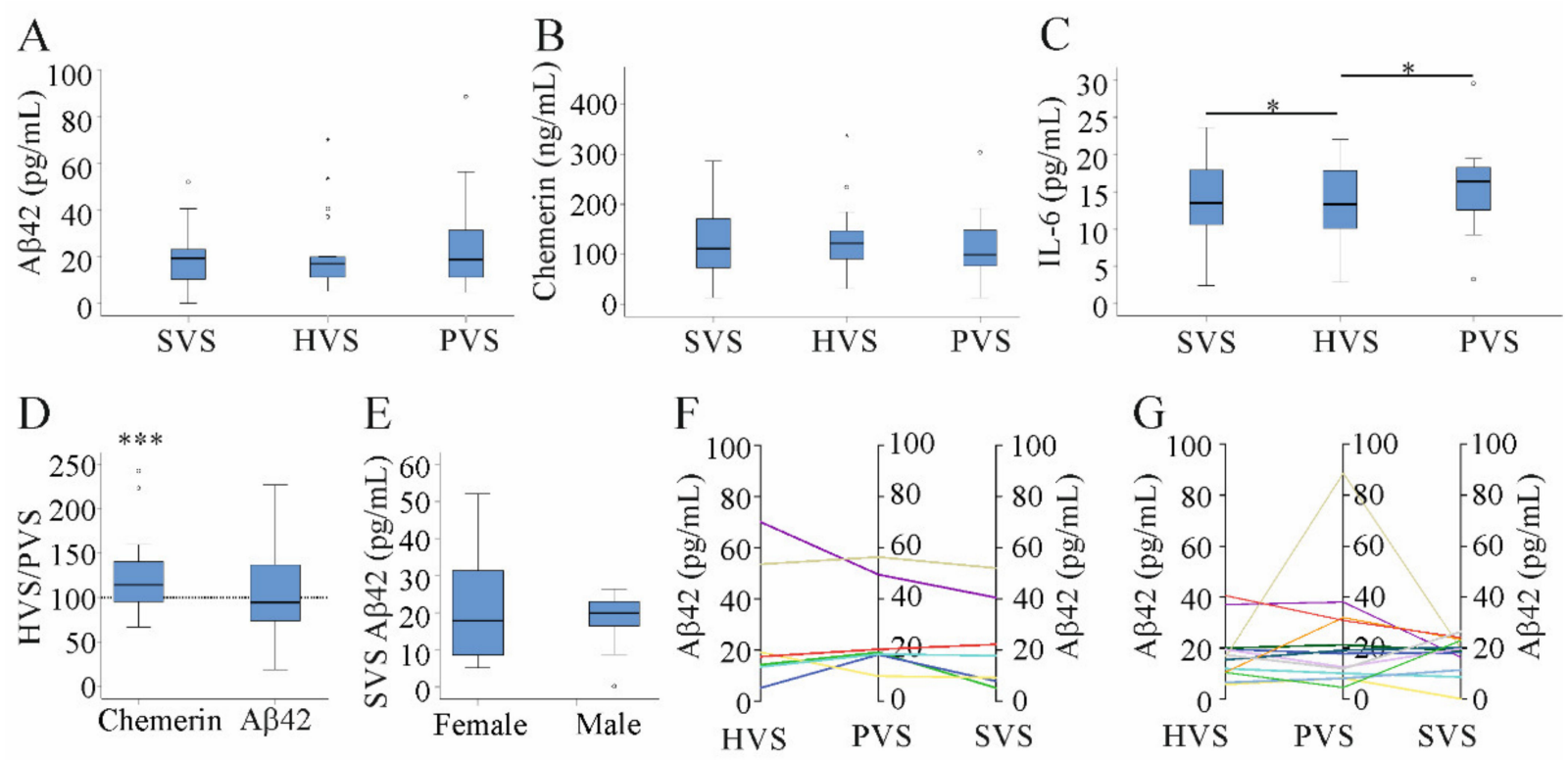

Figure 1. A $\beta 42$, chemerin, and IL-6 in serum of patients with liver cirrhosis. (A) A $\beta 42$, (B) chemerin, and (C) IL-6 in systemic venous (SVS), hepatic venous (HVS), and portal venous (PVS) serum of patients with liver cirrhosis. (D) HVS/PVS ratio of chemerin and A $\beta 42$ in \%. The dotted line is the $100 \%$ value. (E) SVS A $\beta 42$ in females and males. (F) A $\beta 42$ in HVS, PVS, and SVS of female and (G) male patients. ${ }^{*} p<0.05,{ }^{* * *} p<0.001$. 
Small effects can be more easily identified when looking at the respective ratios. The mean of the chemerin HVS/PVS ratio was $123 \%$, whereas the A $\beta 42 \mathrm{HVS} / \mathrm{PVS}$ ratio was $103 \%$. The chemerin HVS/PVS ratio was increased relative to the value of $100 \%$, which indicated that the ratio did not change (Wilcoxon Test; Figure 1D).

A $\beta 42$ levels in SVS, HVS, and PVS did not differ between male and female patients (Mann-Whitney U Test; Figure 1E-G). A $\beta 42$ levels in HVS, PVS, and SVS of the individual patients showed that levels of most patients were similar in the three blood compartments (Figure 1F,G).

It has to be noted that systemic $A \beta 42$ levels did not correlate with patients' ages $(\mathrm{r}=0.312, p=0.181)$. Median A $\beta 42$ level in SVS of the two patients infected with hepatitis $C$ virus was $16.1 \mathrm{pg} / \mathrm{mL}$ and was $19.7 \mathrm{pg} / \mathrm{mL}$ in the patients with alcoholic cirrhosis, suggesting that serum $A \beta 42$ was not changed much by hepatitis $C$ infection.

In general, there is a very good correlation between the metabolite concentrations in SVS, HVS, and PVS [29]. This was the case for chemerin and IL-6 levels in the current cohort (Table 2). Correlations for A $\beta 42$ in SVS, PVS, and HVS were also significant. The correlation coefficients were, however, smaller (Spearman correlations; Table 2). A correlation coefficient of 0.838 for PVS and HVS chemerin corresponded to a coefficient of determination $\left(\mathrm{R}^{2}\right)$ of 0.702 , suggesting that about $70 \%$ of HVS chemerin can be explained by its PVS levels. $\mathrm{R}^{2}$ for PVS and HVS A $\beta 42$ was 0.347 , and about $65 \%$ of the variability in HVS must be related to other factors than the A $\beta 42$ PVS levels [46].

Table 2. Spearman correlation coefficients and $p$-values (in brackets) for chemerin, IL-6, and A $\beta 42$ levels in the blood compartments.

\begin{tabular}{ccc}
\hline & HVS A $\beta 42$ & PVS A $\beta 42$ \\
\hline SVS A $\beta 42$ & $0.541(0.014)$ & $0.463(0.040)$ \\
HVS A $\beta 42$ & & $0.589(0.006)$ \\
\hline & HVS Chemerin & PVS Chemerin \\
\hline SVS Chemerin & $0.811(<0.001)$ & $0.912(<0.001)$ \\
HVS Chemerin & & $0.838(<0.001)$ \\
\hline SVS IL-6 & HVS IL-6 & PVS IL-6 \\
HVS IL-6 & $0.950(<0.001)$ & $0.689(0.001)$ \\
\hline
\end{tabular}

HVS: Hepatic venous serum; IL-6: Interleukin-6; PVS: Portal venous serum; SVS: Systemic venous serum.

\subsection{A 42 in Relation to Scores and Measures of Liver Function}

The calculation of the Child-Pugh score uses bilirubin, albumin, international normalized ratio (INR), ascites, and encephalopathy. The model for end-stage liver disease (MELD) score is calculated from bilirubin, INR, and creatinine [47]. Levels of A $\beta 42$ were similar in patients with Child-Pugh scores A, B, and C (Kruskal-Wallis Test; Figure 2A). The median MELD score was 9, and A $\beta 42$ did not differ between patients with a MELD score below or equal to 9 and patients with a MELD score above this median value (Mann-Whitney $\mathrm{U}$ Test; Figure 2B). Classification of patients according to normal and abnormal bilirubin levels, creatinine levels, or Quick prothrombin time did not reveal any differences in $A \beta 42$ levels between the groups (Mann-Whitney U Test; Figure 2C-E). Accordingly, A $\beta 42$ in serum did not correlate with serum albumin (Spearman correlation, Figure 2F).

\subsection{A 442 in Patients with Disturbed Glucose Metabolism}

Type 2 diabetes increases the risk for Alzheimer disease [24,48]. In our cohort, diabetic patients had higher $A \beta 42$ serum levels in comparison to the non-diabetic patients. This effect was significant in HVS $(p=0.047)$ but not in PVS $(p=0.069)$ and SVS $(p=0.181)$ (MannWhitney U Test; Figure 3A). HVS/PVS A $\beta 42$ ratio (Mann-Whitney U Test; $p=0.910$ ) did not differ between diabetic and non-diabetic patients. 

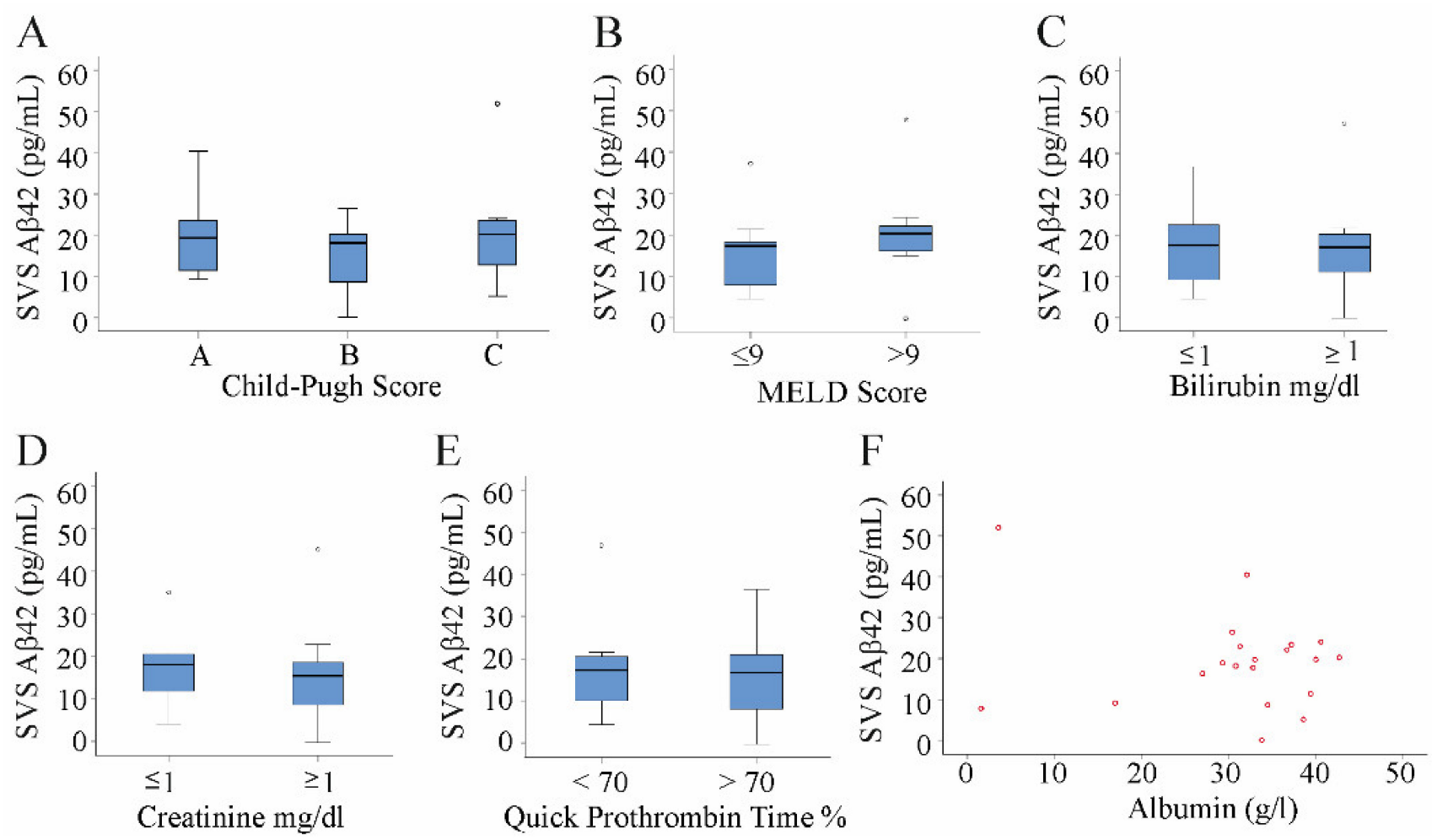

Figure 2. $A \beta 42$ in relation to liver function. $A \beta 42$ in serum of patients with liver cirrhosis stratified for (A) the Child-Pugh score $(\mathrm{A}=$ six patients, $\mathrm{B}=$ six patients, and $\mathrm{C}=$ eight patients) or $(\mathrm{B})$ the median MELD score (nine patients had a MELD above 9 and 11 patients a MELD score $\leq 9)$. (C) A $\beta 42$ serum levels in patients with a bilirubin value below (eight patients) or above (12 patients) the upper normal value ( $1 \mathrm{mg} / \mathrm{dL}$ ). (D) A $\beta 42$ serum levels in patients with creatinine levels below (eight patients) or above (12 patients) the upper normal value $(1 \mathrm{mg} / \mathrm{dL})$. (E) A $\beta 42$ serum levels in patients with a normal $(<70 \%, 10$ patients) or a prolonged ( $>70 \%, 10$ patients) Quick prothrombin time. (F) Spearman analysis showed that A $\beta 42$ serum levels did not correlate with albumin in the 20 patients.

\subsection{Association of A 42 Levels with Markers of Inflammation, Endothelial Function, and Fibrosis}

Systemic inflammation contributes to Alzheimer disease [49,50]. However, serum A $\beta 42$ was not correlated with CRP (Table 3). Resistin, chemerin, IL-6, and visfatin were all described to be associated with inflammation [35,51-53], but serum A $\beta 42$ did not correlate with any of these molecules (Spearman correlation; Table 3).

There was evidence that $A \beta 42$ induced endothelial NO synthase production in the liver [13]. Serum arginine and ADMA are markers of endothelial function and were already measured in the serum of those patients [22,23,54]. Serum A $\beta 42$ did not correlate with arginine and/or ADMA levels (Spearman correlation; Table 3).

Recent studies showed anti-fibrotic effects of A $\beta 42$ [13]. CTGF was identified as a serum marker of ongoing fibrosis [17] and negatively correlated with SVS A $\beta 42$ (Spearman correlation; Table 3, Figure 3B). HVS ( $r=-0.253, p=0.283)$ or PVS $(\mathrm{r}=0.038, p=0.875)$ levels of these proteins were not correlated. Of note, HVS/PVS A $\beta 42$ ratio negatively correlated with CTGF in PVS $(\mathrm{r}=-0.541, p=0.014)$, HVS $(\mathrm{r}=-0.451, p=0.046)$, and SVS $(\mathrm{r}=-0.489, p=0.029)$.

\subsection{A $\beta 42$ in Patients with Ascites and Varices}

Increased splanchnic and reduced hepatic NO production in liver cirrhosis contribute to portal hypertension [21]. A $\beta 42$ did not correlate with the hepatic venous pressure gradient (Spearman correlation; $\mathrm{r}=0.217, p=0.358$ for SVS; $\mathrm{r}=-0.77, p=0.747$ for HVS; $\mathrm{r}=-0.311, p=0.182$ for PVS). Esophageal varices and ascites are common complications of portal hypertension [55]. Systemic A $\beta 42$ was similar in patients with modest/massive ascites in comparison to patients with no/little ascites (Mann-Whitney U Test; Figure 3C). 
Serum $A \beta 42$ did also not change in patients with large varices in relation to patients with no/small varices (Mann-Whitney U Test; Figure 3D).
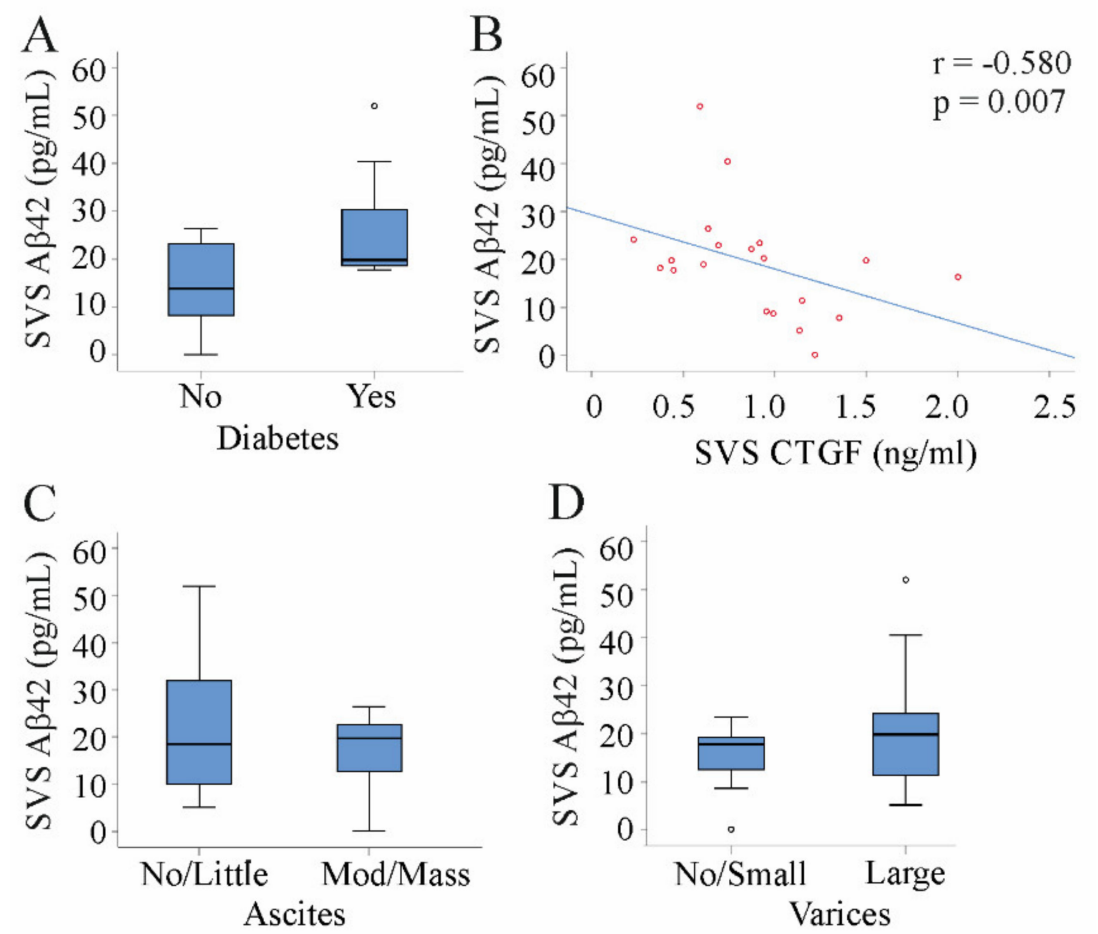

Figure 3. Association of $A \beta 42$ serum levels with diabetes, ascites, and varices. (A) SVS A $\beta 42$ serum levels in 8 patients with and 12 patients without diabetes. (B) Correlation of SVS A $\beta 42$ with serum CTGF. (C) SVS A $\beta 42$ serum levels in eight patients with no/little and 12 patients with moderate/massive ascites. (D) SVS A $\beta 42$ serum levels in seven patients with no/small and 13 patients with large varices.

Table 3. Spearman correlation coefficients ( $r$ ) and $p$-values $(p)$ for the association of systemic A $\beta 42$ with inflammatory markers, proteins with a role in nitric oxide production, and connective tissue growth factor (CTGF).

\begin{tabular}{ccccccccc}
\hline & CRP & Resistin & Chemerin & IL-6 & Visfatin & Arginine & ADMA & CTGF \\
\hline $\mathrm{r}$ & 0.390 & -0.011 & -0.290 & 0.262 & 0.040 & -0.251 & -0.036 & -0.580 \\
$p$ & 0.089 & 0.965 & 0.214 & 0.531 & 0.867 & 0.286 & 0.880 & 0.007 \\
\hline
\end{tabular}

ADMA: Asymmetric dimethylarginine; CTGF: Connective tissue growth factor; CRP: C-reactive protein; IL-6: Interleukin 6.

\section{Discussion}

This study showed that serum $A \beta 42$ levels were similar in portal, hepatic, and systemic serum and were not related to measures of liver function in patients with liver cirrhosis.

Impaired elimination of $A \beta$ has been proposed to contribute to elevated serum and brain levels, and thereby progresses in Alzheimer disease [24,56]. Recent studies suggested a role of the liver for $A \beta$ degradation and removal [24]. Labeled $A \beta 42$ peptides were, indeed, taken up by the liver and excreted in bile [11]. This finding gives, however, no information about the final levels of $A \beta 42$ in the hepatic vein considering that the liver generates and degrades $A \beta$ [13]. PVS and HVS $A \beta 42$ levels were similar in the patients with liver cirrhosis. This suggests that the cirrhotic liver does not eliminate portal-venous $A \beta 42$. It is, however, possible that $A \beta 42$ is taken up by the cirrhotic liver for excretion but is also released from this organ into the circulation. APP mRNA and the enzymes for $A \beta$ production are expressed in the liver [13]. Comparable A $\beta 42$ levels in PVS and HVS are achieved when removal and production rates are similar. PVS and HVS levels 
of most cytokines and chemokines analyzed so far were highly correlated [16,22,31,36,45]. This also applied to chemerin and IL-6 levels in the small study cohort analyzed herein. Correlations of A $\beta 42$ in SVS, PVS, and HVS were smaller and, thus, A $\beta 42$ levels may be more extensively modified when passing the liver.

Whatever the underlying mechanisms are, the present findings indicated that levels of A $\beta 42$ were not significantly reduced when passing the cirrhotic liver. Impaired liver function is associated with a diminished elimination of cytokines such as IL-6, and, accordingly, IL-6 levels increased with higher Child-Pugh score [31,57]. A $\beta 42$ levels did not change in patients with worse liver function as assessed by the MELD score, the Child-Pugh score, and laboratory measures of liver disease severity. This illustrated that serum A $\beta 42$ levels are not correlated with residual liver function in patients with cirrhosis.

It may well be that the healthy liver contributes to A $\beta 42$ elimination. It is, however, difficult to obtain HVS and PVS blood from liver healthy donors. Wang et al. showed increased plasma A $\beta 42$ levels in patients with liver cirrhosis in comparison to healthy controls [12]. This indeed suggests a function of the healthy liver in the regulation of plasma A $\beta 42$ levels. The control group in that study was healthy subjects, and noncirrhotic patients with chronic liver diseases were not included in the analysis by Wang et al. [12]. Patients infected with hepatitis B had about four-fold higher A $\beta 42$ levels than non-infected patients. This shows that hepatitis $B$ infection has a much greater effect on systemic $A \beta 42$ levels than suffering from liver cirrhosis [12]. Current preliminary analysis suggested that hepatitis $C$ infection (only two patients) was not associated with very high A $\beta 42$ serum levels, but this needs further analysis.

It may well be that hepatic $A \beta 42$ release is enhanced in patients with liver cirrhosis, and this may also reduce levels in the liver tissues and increase systemic concentrations of this peptide [12,13].

In an experimental murine NAFLD model, plasma $A \beta 42$ even declined, and analysis of hepatic pathways involved in $A \beta$ synthesis, catabolism, and clearance revealed that all of them were reduced in NAFLD [58]. Beta-secretase 1 was, however, found induced in the liver of $\mathrm{db} / \mathrm{db}$ mice, which have a mutated leptin receptor and liver steatosis [59]. In human liver cirrhosis, beta-secretase 1 and neprilysin, which efficiently degrades the $A \beta$ peptides, were suppressed, suggesting that production and degradation pathways were downregulated [13]. Chronic liver diseases may thus be associated with a dysregulation of $A \beta$ production and removal. Major causes of liver cirrhosis are NAFLD, viral infection, and alcohol abuse [60]. Whether disease etiology may affect the hepatic production or clearance of $A \beta 42$ was not studied so far. Data about expression of hepatic enzymes involved in $\mathrm{A} \beta 42$ metabolism and hepatic and systemic $\mathrm{A} \beta 42$ in patients stratified for etiology of liver cirrhosis are missing.

A $\beta 42$ levels were about three fold higher in the cirrhosis patients studied by Wang et al. in comparison to our cohort. About $30 \%$ of their patients had chronic hepatitis B (HBV) [12]. Plasma A $\beta 42$ levels in the non-HBV patients with liver cirrhosis were about $28 \mathrm{pg} / \mathrm{mL}$, and this is comparable to the SVS A $\beta 42$ levels $(20 \mathrm{pg} / \mathrm{mL})$ identified in our study where mostly patients with alcoholic cirrhosis were included.

The study by Wang et al. described associations of plasma A $\beta 42$ with bilirubin, albumin, and AST concentrations [12]. The correlation analyses included data of non-HBV and HBV patients with liver cirrhosis and healthy controls, and analysis has to be done separately in these three different cohorts [12]. Positive associations of $A \beta 42$ with markers of liver injury such as bilirubin and AST can also be explained by higher hepatic release of $A \beta 42$ from the damaged liver, and a more detailed analysis is needed to characterize the pathways contributing to increased systemic $A \beta 42$ in liver cirrhosis.

Higher age is a risk factor for liver cirrhosis and Alzheimer disease [2,35]. A $\beta 42$ levels were, however, not correlated with age in the current cohort. A very modest negative association of plasma $A \beta 42$ and age was described in cognitively normal subjects [61]. A second analysis showed a relatively weak positive correlation of plasma $A \beta 42$ level and 
age [62]. These opposing reports suggest that correlations of $A \beta 42$ level and age are weak and seem to be cohort specific.

Liver cirrhosis is often associated with chronic inflammation, and various cytokines were found induced in serum of these patients [35]. Plasma A $\beta 42$ levels were, however, not correlated with IL-1 $\beta$, IL-6, TNF, and IFN- $\gamma$ in the study by Wang et al. [12]. In accordance with these findings, serum $A \beta 42$ did not correlate with inflammatory proteins such as IL-6 and CRP in the current cohort. Therefore, it is unlikely that acute phase proteins or inflammatory proteins contribute to increased serum $A \beta 42$.

There is evidence that $A \beta 42$ is increased in obesity and diabetes. Obese mice had elevated plasma $A \beta 42$ levels [63]. In diabetic patients, plasma $A \beta 42$ levels were higher than in non-diabetic controls [63]. Of note, in the patients with liver cirrhosis studied herein, A $\beta 42$ was significantly induced in HVS of diabetic patients with liver cirrhosis. HVS/PVS A $\beta 42$ ratio did not differ between the diabetic and non-diabetic patients excluding that hepatic production was grossly induced in these patients.

A $\beta 42$ was also shown to impair endothelium-dependent and -independent vasodilation and was associated with a lower NO bioavailability [63]. In the aorta of control and high-fat diet-fed mice, A $\beta 42$ reduced phosphorylated endothelial NO synthase protein. On the other hand, it was shown that $A \beta 42$ increased endothelial NO synthase protein in human liver sinusoidal endothelial cells [13]. It is well known that NO is a key factor in the hemodynamic abnormalities of liver cirrhosis. The reduced production of endothelial $\mathrm{NO}$ in the liver and its overproduction in the systemic and splanchnic vasculature are key factors for portal hypertension [21]. Common complications of portal hypertension are ascites and varices [19]. A $\beta 42$ levels were not changed in patients with ascites or varices and did not correlate with the hepatic venous pressure gradient, serum arginine (NO precursor), or ADMA (NO synthase inhibitor) levels. Considering the complex regulation of NO synthesis and the multiple mediators that contribute to portal hypertension [21], this, however, does not exclude a role for $\mathrm{A} \beta 42$ in the regulation of splanchnic and hepatic NO production.

An interesting finding was the negative association of serum CTGF with A $\beta 42$ levels. Serum CTGF was highest in patients with ongoing fibrogenesis [17]. Transforming growth factor $\beta$ (TGF- $\beta$ ) is a strong inducer of hepatocyte CTGF synthesis [18]. A $\beta 42$ reduces TGF- $\beta$ in hepatic stellate cells [13], and this effect may contribute to the negative correlation of CTGF and A $\beta 42$. HVS/PVS A $\beta 42$ ratio was negatively correlated with CTGF in the three blood compartments, assuming a protective role of this peptide in liver cirrhosis.

The main limitation of this study is that only 20 patients were included. Thus, it was not possible to prove small differences. The use of an ELISA, instead of a highly sensitive technique such as the Single Molecule Array (Simoa) ${ }^{\circledR}$ A $\beta 42$ Advantage Kit, is a further limitation of this study. As mentioned above, $A \beta 42$ levels detected in serum of our study cohort were comparable to the levels described in a previous analysis [12]. Moreover, the ELISA used herein was already applied for analysis of serum $A \beta 42$ in a human study cohort [64]. Because of the low levels of $A \beta 42$, serum had to be used undiluted and the specificity of the commercially available ELISA was not thoroughly checked. Medication and alcohol consumption of the patients were not documented and possible effects on serum $A \beta 42$ could not be evaluated. The study strength is that portal vein, hepatic vein, and systemic blood of relatively well-characterized patients were used for analysis of $A \beta 42$.

The present analysis showed that there is no net effect of the cirrhotic liver on $A \beta 42$ levels in the circulation. Further studies are needed to explore the association of $A \beta 42$ levels, ongoing fibrogenesis, and cognitive dysfunction in patients with liver cirrhosis.

Author Contributions: Formal analysis, C.B.; resources, R.W.; writing-original draft preparation, C.B.; conceptualization, writing, review, and editing, T.S.W., L.D., R.W., and C.B. All authors have read and agreed to the published version of the manuscript.

Funding: This research received no external funding. 
Institutional Review Board Statement: The study was conducted according to the guidelines of the Declaration of Helsinki and approved by the Institutional Review Board of the University Hospital Regensburg (protocol code 4/99 and date of approval 20 April 1999).

Informed Consent Statement: Written informed consent was obtained from all subjects involved in the study.

Data Availability Statement: The data presented in this study are available on request from the corresponding author.

Acknowledgments: The technical support of Elena Underberg is greatly appreciated.

Conflicts of Interest: The authors declare no conflict of interest.

\section{References}

1. De Nazareth, A.M. Type 2 diabetes mellitus in the pathophysiology of Alzheimer's disease. Dement. Neuropsychol. 2017, 11, 105-113. [CrossRef] [PubMed]

2. Jellinger, K.A.; Janetzky, B.; Attems, J.; Kienzl, E. Biomarkers for early diagnosis of Alzheimer disease: 'ALZheimer ASsociated gene'-A new blood biomarker? J. Cell. Mol. Med. 2008, 12, 1094-1117. [CrossRef]

3. Van Gool, B.; Storck, S.; Reekmans, S.M.; Lechat, B.; Gordts, P.L.S.M.; Pradier, L.; Pietrzik, C.U.; Roebroek, A.J.M. LRP1 Has a Predominant Role in Production over Clearance of A $\beta$ in a Mouse Model of Alzheimer's Disease. Mol. Neurobiol. 2019, 56, 7234-7245. [CrossRef] [PubMed]

4. Shibata, M.; Yamada, S.; Kumar, S.R.; Calero, M.; Bading, J.; Frangione, B.; Holtzman, D.M.; Miller, C.A.; Strickland, D.K.; Ghiso, J.; et al. Clearance of Alzheimer's amyloid- $\beta 1-40$ peptide from brain by LDL receptor-related protein- 1 at the blood-brain barrier. J. Clin. Investig. 2000, 106, 1489-1499. [CrossRef] [PubMed]

5. Xiang, Y.; Bu, X.-L.; Liu, Y.-H.; Zhu, C.; Shen, L.-L.; Jiao, S.-S.; Zhu, X.-Y.; Giunta, B.; Tan, J.; Song, W.-H.; et al. Physiological amyloid-beta clearance in the periphery and its therapeutic potential for Alzheimer's disease. Acta Neuropathol. 2015, 130, 487-499. [CrossRef] [PubMed]

6. Tian, D.-Y.; Cheng, Y.; Zhuang, Z.-Q.; He, C.-Y.; Pan, Q.-G.; Tang, M.-Z.; Hu, X.-L.; Shen, Y.-Y.; Wang, Y.-R.; Chen, S.-H.; et al. Physiological clearance of amyloid-beta by the kidney and its therapeutic potential for Alzheimer's disease. Mol. Psychiatry 2021, 1-9. [CrossRef]

7. Cheng, Y.; Tian, D.-Y.; Wang, Y.-J. Peripheral clearance of brain-derived A $\beta$ in Alzheimer's disease: Pathophysiology and therapeutic perspectives. Transl. Neurodegener. 2020, 9, 1-11. [CrossRef] [PubMed]

8. Joachim, C.L.; Mori, H.; Selkoe, D.J. Amyloid $\beta$-protein deposition in tissues other than brain in Alzheimer's disease. Nat. Cell Biol. 1989, 341, 226-230. [CrossRef]

9. Chen, S.-H.; Tian, D.-Y.; Shen, Y.-Y.; Cheng, Y.; Fan, D.-Y.; Sun, H.-L.; He, C.-Y.; Sun, P.-Y.; Bu, X.-L.; Zeng, F.; et al. Amyloid-beta uptake by blood monocytes is reduced with ageing and Alzheimer's disease. Transl. Psychiatry 2020, 10, 1-11. [CrossRef]

10. Pappolla, M.; Sambamurti, K.; Vidal, R.; Pacheco-Quinto, J.; Poeggeler, B.; Matsubara, E. Evidence for lymphatic A $\beta$ clearance in Alzheimer's transgenic mice. Neurobiol. Dis. 2014, 71, 215-219. [CrossRef]

11. Ghiso, J.; Shayo, M.; Calero, M.; Ng, D.; Tomidokoro, Y.; Gandy, S.; Rostagno, A.; Frangione, B. Systemic Catabolism of Alzheimer's A $\beta 40$ and A $\beta 42$. J. Biol. Chem. 2004, 279, 45897-45908. [CrossRef]

12. Wang, Y.-R.; Wang, Q.-H.; Zhang, T.; Liu, Y.-H.; Yao, X.-Q.; Zeng, F.; Li, J.; Zhou, F.-Y.; Wang, L.; Yan, J.-C.; et al. Associations Between Hepatic Functions and Plasma Amyloid-Beta Levels-Implications for the Capacity of Liver in Peripheral Amyloid-Beta Clearance. Mol. Neurobiol. 2017, 54, 2338-2344. [CrossRef]

13. Buniatian, G.H.; Weiskirchen, R.; Weiss, T.S.; Schwinghammer, U.; Fritz, M.; Seferyan, T.; Proksch, B.; Glaser, M.; Lourhmati, A.; Buadze, M.; et al. Antifibrotic Effects of Amyloid-Beta and Its Loss in Cirrhotic Liver. Cells 2020, 9, 452. [CrossRef]

14. Roher, A.E.; Esh, C.L.; Kokjohn, T.A.; Castaño, E.M.; Van Vickle, G.D.; Kalback, W.M.; Patton, R.L.; Luehrs, D.C.; Daugs, I.D.; Kuo, Y.-M.; et al. Amyloid beta peptides in human plasma and tissues and their significance for Alzheimer's disease. Alzheimer's Dement. 2009, 5, 18-29. [CrossRef]

15. Molinuevo, J.L.; Ayton, S.; Batrla, R.; Bednar, M.M.; Bittner, T.; Cummings, J.; Fagan, A.M.; Hampel, H.; Mielke, M.; Mikulskis, A.; et al. Current state of Alzheimer's fluid biomarkers. Acta Neuropathol. 2018, 136, 821-853. [CrossRef]

16. Bauer, S.; Eisinger, K.; Wiest, R.; Karrasch, T.; Scherer, M.N.; Farkas, S.; Aslanidis, C.; Buechler, C. Connective tissue growth factor level is increased in patients with liver cirrhosis but is not associated with complications or extent of liver injury. Regul. Pept. 2012, 179, 10-14. [CrossRef]

17. Gressner, A.M.; Yagmur, E.; Lahme, B.; Gressner, O.; Stanzel, S. Connective Tissue Growth Factor in Serum as a New Candidate Test for Assessment of Hepatic Fibrosis. Clin. Chem. 2006, 52, 1815-1817. [CrossRef] [PubMed]

18. Gressner, O.A.; Lahme, B.; Demirci, I.; Gressner, A.M.; Weiskirchen, R. Differential effects of TGF- $\beta$ on connective tissue growth factor (CTGF/CCN2) expression in hepatic stellate cells and hepatocytes. J. Hepatol. 2007, 47, 699-710. [CrossRef] [PubMed]

19. Laleman, W.; Landeghem, L.; Wilmer, A.; Fevery, J.; Nevens, F. Portal hypertension: From pathophysiology to clinical practice. Liver Int. 2005, 25, 1079-1090. [CrossRef] [PubMed] 
20. Siramolpiwat, S. Transjugular intrahepatic portosystemic shunts and portal hypertension-related complications. World J. Gastroenterol. 2014, 20, 16996-17010. [CrossRef] [PubMed]

21. Wiest, R.; Groszmann, R.J. The paradox of nitric oxide in cirrhosis and portal hypertension: Too much, not enough. Hepatology 2002, 35, 478-491. [CrossRef]

22. Eisinger, K.; Krautbauer, S.; Wiest, R.; Karrasch, T.; Hader, Y.; Scherer, M.N.; Farkas, S.; Aslanidis, C.; Buechler, C. Portal vein omentin is increased in patients with liver cirrhosis but is not associated with complications of portal hypertension. Eur. J. Clin. Investig. 2013, 43, 926-932. [CrossRef]

23. Lluch, P.; Torondel, B.; Medina, P.; Segarra, G.; Del Olmo, J.A.; Serra, M.A.; Rodrigo, J.M. Plasma concentrations of nitric oxide and asymmetric dimethylarginine in human alcoholic cirrhosis. J. Hepatol. 2004, 41, 55-59. [CrossRef]

24. Estrada, L.D.; Ahumada, P.; Cabrera, D.; Arab, J.P. Liver Dysfunction as a Novel Player in Alzheimer's Progression: Looking Outside the Brain. Front. Aging Neurosci. 2019, 11, 174. [CrossRef]

25. Buechler, C.; Wanninger, J.; Neumeier, M. Adiponectin, a key adipokine in obesity related liver diseases. World J. Gastroenterol. 2011, 17, 2801-2811. [CrossRef] [PubMed]

26. Kim, D.-G.; Krenz, A.; Toussaint, L.E.; Maurer, K.J.; Robinson, S.-A.; Yan, A.; Torres, L.; Bynoe, M.S. Non-alcoholic fatty liver disease induces signs of Alzheimer's disease (AD) in wild-type mice and accelerates pathological signs of AD in an AD model. J. Neuroinflamm. 2016, 13, 1-18. [CrossRef] [PubMed]

27. Nägga, K.; Gustavsson, A.-M.; Stomrud, E.; Lindqvist, D.; Van Westen, D.; Blennow, K.; Zetterberg, H.; Melander, O.; Hansson, O. Increased midlife triglycerides predict brain $\beta$-amyloid and tau pathology 20 years later. Neurology 2017, 90, e73-e81. [CrossRef] [PubMed]

28. Reed, B.; Villeneuve, S.; Mack, W.; DeCarli, C.; Chui, H.C.; Jagust, W. Associations Between Serum Cholesterol Levels and Cerebral Amyloidosis. JAMA Neurol. 2014, 71, 195-200. [CrossRef]

29. Verlinden, W.; Francque, S.; Vonghia, L. Peripheral Venous, Portal Venous, Hepatic Venous, and Arterial and Intrahepatic Cytokine Levels as Biomarkers and Functional Correlations. In Biomarkers in Liver Disease. Biomarkers in Disease: Methods, Discoveries and Applications; Patel, V., Preedy, V., Eds.; Springer: Dordrecht, The Netherlands, 2017. [CrossRef]

30. Fontana, L.; Eagon, J.C.; Trujillo, M.E.; Scherer, P.E.; Klein, S. Visceral Fat Adipokine Secretion Is Associated with Systemic Inflammation in Obese Humans. Diabetes 2007, 56, 1010-1013. [CrossRef]

31. Wiest, R.; Weigert, J.; Wanninger, J.; Neumeier, M.; Bauer, S.; Schmidhofer, S.; Farkas, S.; Scherer, M.N.; Schäffler, A.; Schölmerich, J. Impaired hepatic removal of interleukin-6 in patients with liver cirrhosis. Cytokine 2011, 53, 178-183. [CrossRef]

32. Schmidt-Arras, D.; Rose-John, S. IL-6 pathway in the liver: From physiopathology to therapy. J. Hepatol. 2016, 64, 1403-1415. [CrossRef] [PubMed]

33. Buechler, C.; Eisinger, K.; Krautbauer, S. Diagnostic and prognostic potential of the macrophage specific receptor CD163 in inflammatory diseases. Inflamm. Allergy Drug Targets 2013, 12, 391-402. [CrossRef]

34. Holland-Fischer, P.; Gronbaek, H.; Sandahl, T.D.; Moestrup, S.K.; Riggio, O.; Ridola, L.; Aagaard, N.K.; Møller, H.J.; Vilstrup, H. Kupffer cells are activated in cirrhotic portal hypertension and not normalised by TIPS. Gut 2011, 60, 1389-1393. [CrossRef]

35. Buechler, C.; Haberl, E.M.; Rein-Fischboeck, L.; Aslanidis, C. Adipokines in Liver Cirrhosis. Int. J. Mol. Sci. 2017, 18, 1392. [CrossRef]

36. Eisinger, K.; Krautbauer, S.; Wiest, R.; Weiss, T.S.; Buechler, C. Reduced serum chemerin in patients with more severe liver cirrhosis. Exp. Mol. Pathol. 2015, 98, 208-213. [CrossRef]

37. Krautbauer, S.; Wanninger, J.; Eisinger, K.; Hader, Y.; Beck, M.; Kopp, A.; Schmid, A.; Weiss, T.S.; Dorn, C.; Buechler, C. Chemerin is highly expressed in hepatocytes and is induced in non-alcoholic steatohepatitis liver. Exp. Mol. Pathol. 2013, 95, 199-205. [CrossRef] [PubMed]

38. Buechler, C.; Feder, S.; Haberl, E.M.; Aslanidis, C. Chemerin Isoforms and Activity in Obesity. Int. J. Mol. Sci. 2019, 20, 1128. [CrossRef]

39. Horn, P.; Von Loeffelholz, C.; Forkert, F.; Stengel, S.; Reuken, P.; Aschenbach, R.; Stallmach, A.; Bruns, T. Low circulating chemerin levels correlate with hepatic dysfunction and increased mortality in decompensated liver cirrhosis. Sci. Rep. 2018, 8, 1-9. [CrossRef]

40. Peschel, G.; Grimm, J.; Gülow, K.; Müller, M.; Buechler, C.; Weigand, K. Chemerin Is a Valuable Biomarker in Patients with HCV Infection and Correlates with Liver Injury. Diagnostics 2020, 10, 974. [CrossRef]

41. Gong, C.; Wei, D.; Wang, Y.; Ma, J.; Yuan, C.; Zhang, W.; Yu, G.; Zhao, Y. A Meta-Analysis of C-Reactive Protein in Patients With Alzheimer's Disease. Am. J. Alzheimer's Dis. Dement. 2016, 31, 194-200. [CrossRef] [PubMed]

42. Pieri, G.; Agarwal, B.; Burroughs, A.K. C-reactive protein and bacterial infection in cirrhosis. Ann. Gastroenterol. 2014, 27, 113-120.

43. Hanon, O.; Vidal, J.-S.; Lehmann, S.; Bombois, S.; Allinquant, B.; Tréluyer, J.-M.; Gelé, P.; Delmaire, C.; Blanc, F.; Mangin, J.-F.; et al. Plasma amyloid levels within the Alzheimer's process and correlations with central biomarkers. Alzheimer's Dement. 2018, 14, 858-868. [CrossRef]

44. Roessle, M.; Gerbes, A.L. TIPS for the treatment of refractory ascites, hepatorenal syndrome and hepatic hydrothorax: A critical update. Gut 2010, 59, 988-1000. [CrossRef]

45. Wiest, R.; Moleda, L.; Farkas, S.; Scherer, M.; Kopp, A.; Wönckhaus, U.; Büchler, C.; Schölmerich, J.; Schäffler, A. Splanchnic concentrations and postprandial release of visceral adipokines. Metabolism 2010, 59, 664-670. [CrossRef] [PubMed] 
46. Schober, P.; Boer, C.; Schwarte, L.A. Correlation Coefficients: Appropriate use and interpretation. Anesth. Analg. 2018, 126, 1763-1768. [CrossRef] [PubMed]

47. Angermayr, B.; Cejna, M.; Karnel, F.; Gschwantler, M.; Koenig, F.; Pidlich, J.; Mendel, H.; Pichler, L.; Wichlas, M.; Kreil, A.; et al. Child-Pugh versus MELD score in predicting survival in patients undergoing transjugular intrahepatic portosystemic shunt. Gut 2003, 52, 879-885. [CrossRef]

48. Ott, A.; Stolk, R.; Van Harskamp, F.; Pols, H.A.P.; Hofman, A.; Breteler, M.M. Diabetes mellitus and the risk of dementia: The Rotterdam Study. Neurology 1999, 53, 1937. [CrossRef] [PubMed]

49. Locascio, J.J.; Fukumoto, H.; Yap, L.; Bottiglieri, T.; Growdon, J.H.; Hyman, B.T.; Irizarry, M.C. Plasma Amyloid $\beta$-Protein and C-reactive Protein in Relation to the Rate of Progression of Alzheimer Disease. Arch. Neurol. 2008, 65, 776-785. [CrossRef]

50. Tejera, D.; Mercan, D.; Sanchez-Caro, J.M.; Hanan, M.; Greenberg, D.; Soreq, H.; Latz, E.; Golenbock, D.; Heneka, M.T. Systemic inflammation impairs microglial A $\beta$ clearance through NLRP 3 inflammasome. EMBO J. 2019, 38, e101064. [CrossRef]

51. Genc, H.; Dogru, T.; Kara, M.; Tapan, S.; Ercin, C.N.; Acikel, C.; Karslioglu, Y.; Bagci, S. Association of plasma visfatin with hepatic and systemic inflammation in nonalcoholic fatty liver disease. Ann. Hepatol. 2013, 12, 380-387. [CrossRef]

52. Tilg, H. The Role of Cytokines in Non-Alcoholic Fatty Liver Disease. Dig. Dis. 2010, 28, 179-185. [CrossRef]

53. Bertolani, C.; Sancho-Bru, P.; Failli, P.; Bataller, R.; Aleffi, S.; DeFranco, R.; Mazzinghi, B.; Romagnani, P.; Milani, S.; Ginés, P.; et al. Resistin as an Intrahepatic Cytokine: Overexpression during Chronic Injury and Induction of Proinflammatory Actions in Hepatic Stellate Cells. Am. J. Pathol. 2006, 169, 2042-2053. [CrossRef]

54. Siroen, M.P.C.; Wiest, R.; Richir, M.C.; Teerlink, T.; Rauwerda, J.A.; Drescher, F.T.; Zorger, N.; Leeuwen, P.A.M.V. Transjugular intrahepatic portosystemic shunt-placement increases arginine/asymmetric dimethylarginine ratio in cirrhotic patients. World J. Gastroenterol. 2008, 14, 7214-7219. [CrossRef]

55. Iwakiri, Y. Endothelial dysfunction in the regulation of cirrhosis and portal hypertension. Liver Int. 2011, 32, 199-213. [CrossRef]

56. Maarouf, C.L.; Walker, J.E.; Sue, L.I.; Dugger, B.N.; Beach, T.G.; Serrano, G.E. Impaired hepatic amyloid-beta degradation in Alzheimer's disease. PLoS ONE 2018, 13, e0203659. [CrossRef]

57. Porowski, D.; Wirkowska, A.; Hryniewiecka, E.; Wyzgał, J.; Pacholczyk, M.; Pączek, L. Liver Failure Impairs the Intrahepatic Elimination of Interleukin-6, Tumor Necrosis Factor-Alpha, Hepatocyte Growth Factor, and Transforming Growth Factor-Beta. BioMed Res. Int. 2015, 2015, 1-7. [CrossRef]

58. Pinçon, A.; De Montgolfier, O.; Akkoyunlu, N.; Daneault, C.; Pouliot, P.; Villeneuve, L.; Lesage, F.; Levy, B.I.; Thorin-Trescases, N.; Thorin, É; et al. Non-Alcoholic Fatty Liver Disease, and the Underlying Altered Fatty Acid Metabolism, Reveals Brain Hypoperfusion and Contributes to the Cognitive Decline in APP/PS1 Mice. Metabolites 2019, 9, 104. [CrossRef]

59. Meakin, P.J.; Mezzapesa, A.; Benabou, E.; Haas, M.E.; Bonardo, B.; Grino, M.; Brunel, J.-M.; Desbois-Mouthon, C.; Biddinger, S.B.; Govers, R.; et al. The beta secretase BACE1 regulates the expression of insulin receptor in the liver. Nat. Commun. 2018, 9, 1-14. [CrossRef]

60. Buechler, C.; Aslanidis, C. Role of lipids in pathophysiology, diagnosis and therapy of hepatocellular carcinoma. Biochim. Biophys. Acta (BBA) Mol. Cell Biol. Lipids 2020, 1865, 158658. [CrossRef]

61. Lue, L.-F.; Pai, M.-C.; Chen, T.-F.; Hu, C.-J.; Huang, L.-K.; Lin, W.-C.; Wu, C.-C.; Jeng, J.-S.; Blennow, K.; Sabbagh, M.N.; et al. Age-Dependent Relationship Between Plasma A $\beta 40$ and A $\beta 42$ and Total Tau Levels in Cognitively Normal Subjects. Front. Aging Neurosci. 2019, 11, 222. [CrossRef]

62. Mayeux, R.; Honig, L.S.; Tang, M.-X.; Manly, J.; Stern, Y.; Schupf, N.; Mehta, P.D. Plasma A 40 and A 42 and Alzheimer's disease: Relation to age, mortality, and risk. Neurology 2003, 61, 1185-1190. [CrossRef]

63. Meakin, P.J.; Coull, B.M.; Tuharska, Z.; McCaffery, C.; Akoumianakis, I.; Antoniades, C.; Brown, J.; Griffin, K.J.; Platt, F.; Ozber, C.H.; et al. Elevated circulating amyloid concentrations in obesity and diabetes promote vascular dysfunction. J. Clin. Investig. 2020, 130, 4104-4117. [CrossRef]

64. Ma, F.; Wu, T.; Zhao, J.; Song, A.; Liu, H.; Xu, W.; Huang, G. Folic acid supplementation improves cognitive function by reducing the levels of peripheral inflammatory cytokines in elderly Chinese subjects with MCI. Sci. Rep. 2016, 6, 37486. [CrossRef] 